Article

\title{
Mineral Composition of Organically Grown Wheat Genotypes: Contribution to Daily Minerals Intake
}

\author{
Abrar Hussain *, Hans Larsson, Ramune Kuktaite and Eva Johansson \\ Department of Agriculture-Farming Systems, Technology and Product Quality, Faculty of Landscape \\ Planning, Horticulture and Agriculture Science, The Swedish University of Agricultural Sciences, \\ Box 104, SE-23053 Alnarp, Sweden; E-Mails: Hans.Larsson@ltj.slu.se (H.L.); \\ Ramune.Kuktaite@1tj.slu.se (R.K.); Eva.Johansson@1tj.slu.se (E.J.) \\ * Author to whom correspondence should be addressed; E-Mail: Abrar.Hussain@1tj.slu.se; \\ Tel.: +46-76-2528528; Fax: +46-40-462166.
}

Received: 16 July 2010; in revised form: 1 September 2010 / Accepted: 2 September 2010 / Published: 6 September 2010

\begin{abstract}
In this study, 321 winter and spring wheat genotypes were analysed for twelve nutritionally important minerals (B, Cu, Fe, Se, Mg, Zn, Ca, Mn, Mo, P, S and K). Some of the genotypes used were from multiple locations and years, resulting in a total number of 493 samples. Investigated genotypes were divided into six genotype groups i.e., selections, old landraces, primitive wheat, spelt, old cultivars and cultivars. For some of the investigated minerals higher concentrations were observed in selections, primitive wheat, and old cultivars as compared to more modern wheat material, e.g., cultivars and spelt wheat. Location was found to have a significant effect on mineral concentration for all genotype groups, although for primitive wheat, genotype had a higher impact than location. Spring wheat was observed to have significantly higher values for $\mathrm{B}, \mathrm{Cu}, \mathrm{Fe}$, $\mathrm{Zn}, \mathrm{Ca}, \mathrm{S}$ and $\mathrm{K}$ as compared to winter wheat. Higher levels of several minerals were observed in the present study, as compared to previous studies carried out in inorganic systems, indicating that organic conditions with suitable genotypes may enhance mineral concentration in wheat grain. This study also showed that a very high mineral concentration, close to daily requirements, can be produced by growing specific primitive wheat genotypes in an organic farming system. Thus, by selecting genotypes for further breeding, nutritional value of the wheat flour for human consumption can be improved.
\end{abstract}


Keywords: organic genotypes; minerals; locations; spring and winter wheat; concentrations; food requirements

\section{Introduction}

Minerals are important components required by humans in their daily food. Minerals are divided into two groups: (i) macro minerals, which are needed in large amounts, e.g., calcium (Ca), magnesium $(\mathrm{Mg})$ and potassium $(\mathrm{K})$, etc., and (ii) micro minerals or trace elements, which are required in smaller quantities, e.g., copper $(\mathrm{Cu})$, zinc $(\mathrm{Zn})$, iron $(\mathrm{Fe})$, boron $(\mathrm{B})$, selenium (Se) [1]. All body processes depend upon the action of minerals to activate enzymes performing metabolic functions. Deficiency of specific minerals may lead to various chronic diseases [2,3]. Due to the high consumption of wheat in a variety of food products all over the world, wheat is considered an important source of minerals [4]. The concentration of minerals in wheat flour is genetically determined by the choice of cultivar and environmentally determined by soil, climate and management practices [5]. Concentration of minerals in wheat products can be increased by using whole grain flour instead of white flour. Also, suitable conditions together with selection of wheat cultivars that have a high mineral concentration, can be used to promote high mineral bioavailability [6]. Mineral concentration variability in cultivars has been studied by several authors using wheat grown in inorganic systems [5,7-12]. New techniques present today, allow investigations of a much higher number of minerals, as well as better accuracy as compared to the majority of the above mentioned studies.

Organic and inorganic growing conditions have been shown to have a great impact on the mineral concentrations of wheat grain [13-15]. For example, the concentrations of $\mathrm{P}$ and $\mathrm{Mg}$ were significantly higher in wheat varieties grown under inorganic conditions as compared with those produced organically [16]. The area under organic wheat production represents $18 \%$ of total arable organic land in Europe [17]. Reasons stated for increasing the area under organic production are: environmental concerns, increased nutritional quality and increased safety. Therefore, farmers are getting financial incentives from governments to convert the farming system from inorganic to organic [18].

In the present Western world society there is an increasing demand for and interest in high nutritional products. Organically grown food is seen by many as a nutritionally better solution as compared to conventionally produced food [19].

Primitive wheats such as Einkorn (Triticum monococcum) and Emmer ( $T$. dicoccum) have been found to have high nutritional values in various aspects [20]. For example Einkorn has a high level of carotenoids and high protein concentration, compared to modern wheat [20]. Primitive wheat is the earliest cultivated form of wheat in organic farming system [21]. Thus, organically grown primitive species might be an optimal way of producing nutritional high value food. To our knowledge, there have been no investigations in which variation in mineral concentration among cultivars of different genetic background under organic cultivation has been studied.

The aim of this work was to screen wheat genotypes for mineral concentration under organic cultivation system conditions and to evaluate opportunities to produce wheat with exceptional high concentrations of minerals. The objective was also to evaluate differences in mineral composition 
between common and primitive wheats. Finally, another aim was to study location effects on mineral concentration.

\section{Material and Methods}

\subsection{Sample Collection and Preparation}

Wheat genotypes were collected mainly from the Nordic Gene Bank. Three hundred and twenty one winter and spring wheat genotypes were used for this study (Supplementary Table 1). These genotypes were grown organically during 2001-2007 at four locations in Sweden: Alnarp (55³9.4 N, $13^{\circ} 5.2 \mathrm{E}$ ),

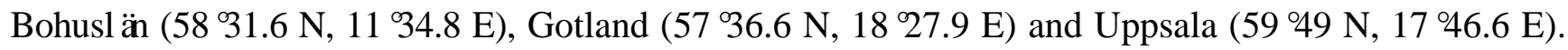
The soil type and characteristics are described in Table 1. Some of the genotypes used in the present study were therefore from multiple locations and years, resulting in a total number of 493 samples being available for analysis. The investigated genotypes could be divided into six genotype groups, i.e., selections $(n=32)$, comprising wheat that has been selected for the purpose of organic cultivation from old material (spelt, durum and bread wheat breeding lines of), old landraces $(n=107)$, primitive wheat $(\mathrm{n}=32$ ) characterised by Einkorn (Triticum monococcum) and Emmer (T. dicoccum), spelt wheat $(\mathrm{n}=103)$, old cultivars $(\mathrm{n}=191)$ from 1900-1960, cultivars $(\mathrm{n}=28)$ after 1970 (Supplementary Table 1). Plant height was measured from soil surface to tip of the spike, awns not included. Yield data was calculated for 28 genotypes which were grown in bigger plots in Bohuslän.

Table 1. General characteristics of soil at different locations.

\begin{tabular}{cccccccc}
\hline Location & $\mathbf{p H}^{\mathbf{a}}$ & $\begin{array}{c}\text { Organic } \\
\text { matter (\%) }\end{array}$ & clay (\%) & $\begin{array}{c}\text { P-AL } \\
(\mathbf{m g} / \mathbf{1 0 0 g})\end{array}$ & $\begin{array}{c}\mathbf{K}^{\mathbf{b}} \mathbf{- A l}{ }^{\mathbf{b}} \\
(\mathbf{m g} / \mathbf{1 0 0 g})\end{array}$ & FYM & $\begin{array}{c}\text { Organic } \\
\text { since }\end{array}$ \\
\hline Alnarp & $7.0-7.8$ & 3 & 25 & 10.5 & 10.2 & $\begin{array}{c}\text { Not } \\
\text { applied }\end{array}$ & 1992 \\
Bohuslän & $6.4-6.5$ & 4 & 25 & 5.4 & 10.6 & Applied & 1995 \\
Gotland & $7.0-7.5$ & 3 & 10 & 9.6 & 18.2 & Applied & 1987 \\
Uppsala & $6.0-6.2$ & 5 & 50 & 9.9 & 46.2 & Applied & 1990 \\
\hline \multicolumn{7}{c}{${ }^{\mathrm{a}}$ from soil-water sample; ${ }^{\mathrm{b}}$ P-Al and K-Al methods used [23]. }
\end{tabular}

About $40 \mathrm{~g}$ of each grain sample was milled to flour (whole grain) for $1 \mathrm{~min}$ with a laboratory mill (Yellow line, A10, IKA-Werke, Staufen, Germany). Afterward the flour samples were stored at $-20{ }^{\circ} \mathrm{C}$.

\subsection{Sample Drying and Digestion}

All the samples were dried in an oven at $40{ }^{\circ} \mathrm{C}$ for $24 \mathrm{~h}$ and $0.5 \mathrm{~g}$ of each flour sample was measured and digested with microwave digester (microwave labstation Mars 5, CEM Corporation, Mathews, $\mathrm{NC}$, USA) using $10 \mathrm{~mL}$ of concentrated nitric acid $\left(\mathrm{HNO}_{3}\right)$. The digested samples were diluted with water to $100 \mathrm{~mL}$ before analysis. 


\subsection{Chemical Analysis}

The mineral concentration in the solutions was measured by using Inductively Coupled Plasma Mass Spectrometry (ICP-MS; Perkin-Elmer, ELAN-6000) and by Inductively Coupled Plasma Atomic Emission Spectrometry (ICP-OES; Perkin-Elmer, OPTIMA 3000 DV). Standards used in the analysis were atomic spectrometry standards from Perkin-Elmer, SPEX, AccuStandard and Merck.

Calibration of the ICP-OES instrument was done by using a mixed multicomponent standard at three concentrations within the factor of 50 and calibration was maintained with independent standards. The ICP-MS instrument was calibrated against four mixed standards. Among these four, three were prepared from a single element standard and one was the Merck's ICP multi element standard IV. Rhodium was added to all samples and standard solutions as an internal standard.

Mineral elements $\mathrm{Al}, \mathrm{B}, \mathrm{Ba}, \mathrm{Ca}, \mathrm{Cu}, \mathrm{Fe}, \mathrm{K}, \mathrm{Mg}, \mathrm{Mn}, \mathrm{Na}, \mathrm{P}, \mathrm{S}, \mathrm{Sr}$, Ti and $\mathrm{Zn}$ were determined by ICP-OES. Other elements measured by ICP-MS (isotopes used indicated) were ${ }^{75} \mathrm{As},{ }^{59} \mathrm{Co},{ }^{52} \mathrm{Cr}$, ${ }^{202} \mathrm{Hg},{ }^{7} \mathrm{Li},{ }^{95} \mathrm{Mo},{ }^{58} \mathrm{Ni},{ }^{208} \mathrm{~Pb},{ }^{121} \mathrm{Sb},{ }^{82} \mathrm{Se},{ }^{120} \mathrm{Sn},{ }^{51} \mathrm{~V}$. Blanks were treated identically and together with samples. Detection limits of minerals determined, expressed as three time the standard deviation $(3 \times$ S.D. $)$ and calculated for multiple determination of the blanks treated as the samples, were reported by [22]. All analyses were performed at the ICP laboratory, Department of Ecology, Lund University, which has 30 year experience of mineral analysis and participate in regular national and international multi-element calibration tests, always with very good results. The concentration for each element was calculated as absolute concentration $\mathrm{mg} / \mathrm{kg}$.

\subsection{Statistical Analysis}

Analysis of Variance (ANOVA), Spearman rank correlation and variances were calculated by using Statistical Analysis System (SAS Institute, Cary, NC 1985). The ratio between genetic group and location variances $\left(\sigma_{\mathrm{g}}{ }^{2} / \sigma_{1}{ }^{2}\right)$ was calculated for each of the analysed minerals and genotype groups. This ratio provides a mean for determining relative influences of genotype and location on the mineral composition of wheat. A ratio more than 1.0 indicates greater influence of genotype on variability of minerals and less than 1.0 ratio shows a greater impact of location [9].

\section{Results}

The concentration of 27 minerals was determined in the wheat flour samples and in the present paper variation in the twelve minerals $(\mathrm{B}, \mathrm{Cu}, \mathrm{Fe}, \mathrm{Se}, \mathrm{Mg}, \mathrm{Zn}, \mathrm{Ca}, \mathrm{Mn}, \mathrm{Mo}, \mathrm{P}, \mathrm{S}$ and $\mathrm{K}$ ) that are essential for good preventive nutrition of human are evaluated and discussed.

\subsection{Genotypic Differences}

Substantial differences in the concentration of grain minerals were found among genotype and genotype groups (Table 2). Selections showed significantly the highest concentration of Se $(0.18 \mathrm{mg} / \mathrm{kg})$ among the genotype groups. High concentrations of Fe (35.8 mg/kg), Mg (1330 mg/kg), Mn (23.7 mg/kg), Mo $(2.58 \mathrm{mg} / \mathrm{kg}), \mathrm{P}(4,670 \mathrm{mg} / \mathrm{kg})$ and $\mathrm{S}(1,310 \mathrm{mg} / \mathrm{kg})$ were also found in the selections as compared to several of the other genotype groups (Table 2). 
Table 2. Mean concentration of minerals $(\mathrm{mg} / \mathrm{kg}$ ) among genotype groups, locations and wheat type for a total number of 493 wheat samples.

\begin{tabular}{|c|c|c|c|c|c|c|c|c|c|c|c|c|c|}
\hline & & B & $\mathbf{C u}$ & Se & $\mathrm{Fe}$ & Mg & $\mathbf{Z n}$ & $\mathbf{C a}$ & Mn & Mo & $\mathbf{P}$ & $\mathbf{S}$ & $\mathbf{K}$ \\
\hline Selections & $\mathrm{n}=32$ & $1.59 \mathrm{c}$ & $5.27 \mathrm{~b}$ & $0.18 \mathrm{a}$ & $35.8 \mathrm{abc}$ & $1,330 \mathrm{a}$ & $41.6 \mathrm{~b}$ & $358 \mathrm{~b}$ & $23.7 \mathrm{a}$ & $2.58 \mathrm{a}$ & $4,670 \mathrm{a}$ & $1,310 \mathrm{ab}$ & $4,050 \mathrm{~b}$ \\
\hline Old cultivars & $\mathrm{n}=191$ & $1.90 \mathrm{bc}$ & $5.10 \mathrm{~b}$ & $0.10 \mathrm{~b}$ & $39.4 \mathrm{a}$ & $1,220 \mathrm{c}$ & $38.1 \mathrm{bc}$ & $390 \mathrm{a}$ & $24.2 \mathrm{a}$ & $1.53 \mathrm{~b}$ & $3,890 \mathrm{~d}$ & $1,260 \mathrm{bc}$ & $3,980 \mathrm{~b}$ \\
\hline Primitive & $\mathrm{n}=32$ & $2.41 \mathrm{a}$ & $5.75 \mathrm{a}$ & $0.11 \mathrm{~b}$ & $32.2 \mathrm{c}$ & $1,300 \mathrm{ab}$ & $45.6 \mathrm{a}$ & $383 \mathrm{ab}$ & $17.6 \mathrm{c}$ & $1.36 \mathrm{~b}$ & $4,540 \mathrm{a}$ & $1,350 \mathrm{a}$ & $4,670 \mathrm{a}$ \\
\hline Spelt & $\mathrm{n}=103$ & $1.95 \mathrm{bc}$ & $5.50 \mathrm{ab}$ & $0.10 \mathrm{~b}$ & $38.0 \mathrm{ab}$ & $1,280 \mathrm{abc}$ & $39.2 \mathrm{bc}$ & $327 \mathrm{c}$ & $20.0 \mathrm{bc}$ & $1.75 \mathrm{~b}$ & $4,280 \mathrm{~b}$ & $1,360 \mathrm{a}$ & $4,150 \mathrm{~b}$ \\
\hline Landraces & $\mathrm{n}=107$ & $2.10 \mathrm{ab}$ & $5.33 \mathrm{~b}$ & $0.09 \mathrm{~b}$ & $38.5 \mathrm{ab}$ & $1,290 \mathrm{ab}$ & $38.1 \mathrm{bc}$ & $408 \mathrm{a}$ & $22.7 \mathrm{ab}$ & $1.66 \mathrm{~b}$ & $4,130 \mathrm{bc}$ & $1,300 \mathrm{abc}$ & $4,000 \mathrm{~b}$ \\
\hline Cultivars & $\mathrm{n}=28$ & $1.59 \mathrm{c}$ & $4.49 \mathrm{c}$ & $0.11 \mathrm{~b}$ & $33.3 \mathrm{bc}$ & $1,240 \mathrm{bc}$ & $36.2 \mathrm{c}$ & $388 \mathrm{a}$ & $23.3 \mathrm{ab}$ & $2.23 \mathrm{a}$ & $4,020 \mathrm{dc}$ & $1,230 \mathrm{c}$ & $4,070 \mathrm{~b}$ \\
\hline Alnarp & $\mathrm{n}=278$ & $1.84 \mathrm{~b}$ & $5.29 \mathrm{~b}$ & $0.15 \mathrm{a}$ & $38.4 \mathrm{~b}$ & $1,300 \mathrm{a}$ & $39.9 \mathrm{~b}$ & $382 \mathrm{~b}$ & $24.2 \mathrm{~b}$ & $2.19 \mathrm{a}$ & $4,470 \mathrm{a}$ & $1,320 \mathrm{~b}$ & $4,180 \mathrm{a}$ \\
\hline Bohuslän & $\mathrm{n}=29$ & $1.45 \mathrm{c}$ & $3.79 \mathrm{c}$ & $0.03 \mathrm{c}$ & $38.2 \mathrm{~b}$ & $1,190 \mathrm{~b}$ & $35.8 \mathrm{c}$ & $330 \mathrm{c}$ & $41.2 \mathrm{a}$ & $1.33 \mathrm{~b}$ & $3,300 \mathrm{~d}$ & $988 \mathrm{c}$ & $3,390 \mathrm{c}$ \\
\hline Gotland & $\mathrm{n}=141$ & $2.33 \mathrm{a}$ & $5.34 \mathrm{ab}$ & $0.04 \mathrm{c}$ & $33.1 \mathrm{c}$ & $1,220 \mathrm{~b}$ & $36.2 \mathrm{c}$ & $369 \mathrm{~b}$ & $17.0 \mathrm{c}$ & $1.13 \mathrm{~b}$ & $3,800 \mathrm{~b}$ & $1,280 \mathrm{~b}$ & $4,070 \mathrm{a}$ \\
\hline Uppsala & $\mathrm{n}=45$ & $1.79 \mathrm{~b}$ & $5.66 \mathrm{a}$ & $0.08 \mathrm{~b}$ & $49.6 \mathrm{a}$ & $1,210 \mathrm{~b}$ & $43.4 \mathrm{a}$ & $411 \mathrm{a}$ & $17.0 \mathrm{c}$ & $0.71 \mathrm{c}$ & $3,500 \mathrm{c}$ & $1,420 \mathrm{a}$ & $3,890 \mathrm{~b}$ \\
\hline Spring wheat ${ }^{a}$ & $\mathrm{n}=176$ & $2.11 \mathrm{a}$ & $5.62 \mathrm{a}$ & $0.10 \mathrm{a}$ & $47.5 \mathrm{a}$ & $1280 \mathrm{a}$ & $41.2 \mathrm{a}$ & $420 \mathrm{a}$ & $22.6 \mathrm{a}$ & $1.32 \mathrm{~b}$ & $3870 \mathrm{~b}$ & $1430 \mathrm{a}$ & $4160 \mathrm{a}$ \\
\hline Winter wheat $^{a}$ & $\mathrm{n}=317$ & $1.86 \mathrm{~b}$ & $5.05 \mathrm{~b}$ & $0.10 \mathrm{a}$ & $32.5 \mathrm{~b}$ & $1250 \mathrm{a}$ & $37.7 \mathrm{~b}$ & $355 \mathrm{~b}$ & $22.5 \mathrm{a}$ & $1.92 \mathrm{a}$ & $4260 \mathrm{a}$ & $1220 \mathrm{~b}$ & $3920 \mathrm{~b}$ \\
\hline
\end{tabular}

Mean values followed by the same letter do not differ significantly from each other. ${ }^{\mathrm{a}}$ Cultivation period for spring and winter wheat are April-August and September-August, respectively. 
Old cultivars were found to have high concentrations of Fe $(39.4 \mathrm{mg} / \mathrm{kg}), \mathrm{Ca}(390 \mathrm{mg} / \mathrm{kg})$ and $\mathrm{Mn}$ $(24.2 \mathrm{mg} / \mathrm{kg})$ as compared to several other genotype groups. Concentrations of B $(1.90 \mathrm{mg} / \mathrm{kg}), \mathrm{Se}$ (0.10 mg/kg), Mg (1,220 mg/kg), Zn (38.1 mg/kg), Mo (1.53 mg/kg), P (3,890 mg/kg) and K (3,980 mg/kg) were observed to be relatively low in old cultivars among the genotype groups (Table 2).

Primitive wheat showed significantly the highest concentrations of $\mathrm{Zn}(45.6 \mathrm{mg} / \mathrm{kg})$ and $\mathrm{K}(4,670 \mathrm{mg} / \mathrm{kg})$ compared to all other genotype groups. Grain concentrations of B $(2.41 \mathrm{mg} / \mathrm{kg}), \mathrm{Cu}(5.75 \mathrm{mg} / \mathrm{kg}), \mathrm{Mg}$ $(1,300 \mathrm{mg} / \mathrm{kg}), \mathrm{Ca}(383 \mathrm{mg} / \mathrm{kg}), \mathrm{P}(4,540 \mathrm{mg} / \mathrm{kg})$ and $\mathrm{S}(1,350 \mathrm{mg} / \mathrm{kg})$ were also observed to be high in primitive wheat compared to the rest of the genotype groups. Primitive wheat revealed relatively low magnitude for Se $(0.11 \mathrm{mg} / \mathrm{kg}), \mathrm{Fe}(32.2 \mathrm{mg} / \mathrm{kg}), \mathrm{Mn}(17.6 \mathrm{mg} / \mathrm{kg})$ and Mo $(1.36 \mathrm{mg} / \mathrm{kg})$ compared to the other genotype groups (Table 2).

Spelt wheat showed high concentrations of $\mathrm{Cu}(5.50 \mathrm{mg} / \mathrm{kg}), \mathrm{Fe}(38.0 \mathrm{mg} / \mathrm{kg})$ and $\mathrm{S}(1,360 \mathrm{mg} / \mathrm{kg})$ as related to the other genotype groups. This group showed low grain concentrations of B $(1.95 \mathrm{mg} / \mathrm{kg})$, Se $(0.10 \mathrm{mg} / \mathrm{kg}), \mathrm{Zn}(39.2 \mathrm{mg} / \mathrm{kg}), \mathrm{Ca}(327 \mathrm{mg} / \mathrm{kg}), \mathrm{Mn}(20.0 \mathrm{mg} / \mathrm{kg})$, Mo $(1.75 \mathrm{mg} / \mathrm{kg})$ and $\mathrm{K}(4,150 \mathrm{mg} / \mathrm{kg})$ as compared to the other groups (Table 2).

Grain concentrations of B $(2.10 \mathrm{mg} / \mathrm{kg}), \mathrm{Fe}(38.5 \mathrm{mg} / \mathrm{kg}), \mathrm{Mg}(1,290 \mathrm{mg} / \mathrm{kg}), \mathrm{Ca}(408 \mathrm{mg} / \mathrm{kg})$ and $\mathrm{Mn}(22.7 \mathrm{mg} / \mathrm{kg})$ in landraces were high compared to the rest of the genotype groups. Low concentrations of Se $(0.09 \mathrm{mg} / \mathrm{kg}), \mathrm{Zn}(38.1 \mathrm{mg} / \mathrm{kg})$, Mo $(1.66 \mathrm{mg} / \mathrm{kg})$ and $\mathrm{K}(4,000 \mathrm{mg} / \mathrm{kg})$ were found in landraces as related to the rest of the groups (Table 2).

Cultivars were detected to have high grain concentrations of Ca $(388 \mathrm{mg} / \mathrm{kg}), \mathrm{Mn}(23.3 \mathrm{mg} / \mathrm{kg})$, Mo $(2.23 \mathrm{mg} / \mathrm{kg})$, and low concentrations of B (1.59 mg/kg), Cu (4.49 mg/kg), Se (0.11 mg/kg), Fe (33.3 mg/kg), $\mathrm{Mg}(1,240 \mathrm{mg} / \mathrm{kg}), \mathrm{Zn}(36.2 \mathrm{mg} / \mathrm{kg}), \mathrm{P}(4,020 \mathrm{mg} / \mathrm{kg})$ and $\mathrm{S}(1,230 \mathrm{mg} / \mathrm{kg})$ as compared to the other genotype groups (Table 2).

\subsection{Difference among Locations}

Significant differences were found among the four locations in concentration of all minerals evaluated in the present paper (Table 2). Wheat grain samples from Alnarp showed significantly the highest concentrations of Se $(0.15 \mathrm{mg} / \mathrm{kg}), \mathrm{Mg}(1,300 \mathrm{mg} / \mathrm{kg})$, Mo $(2.19 \mathrm{mg} / \mathrm{kg})$ and $\mathrm{P}(4,470 \mathrm{mg} / \mathrm{kg})$ as compared to the other three locations. High concentration of $\mathrm{K}(4,180 \mathrm{mg} / \mathrm{kg})$ was also found in the samples from Alnarp (Table 2).

Bohuslän wheat grain samples showed significantly the lowest B $(1.45 \mathrm{mg} / \mathrm{kg}), \mathrm{Cu}(3.79 \mathrm{mg} / \mathrm{kg})$, $\mathrm{Ca}(330 \mathrm{mg} / \mathrm{kg}), \mathrm{P}(3,300 \mathrm{mg} / \mathrm{kg}), \mathrm{S}(988 \mathrm{mg} / \mathrm{kg})$ and $\mathrm{K}(3,390 \mathrm{mg} / \mathrm{kg})$ concentrations among all locations. Concentrations of Se (0.03 mg/kg), Mg (1,190 mg/kg), Zn (35.8 mg/kg) were also found to be low in grain samples from Bohuslän. Mn $(41.2 \mathrm{mg} / \mathrm{kg})$ in grains from Bohuslän was significantly higher than in those from Alnarp, Gotland and Uppsala (Table 2).

Grain concentrations of B $(2.33 \mathrm{mg} / \mathrm{kg})$ were significantly higher in samples from Gotland than in those from all other locations. $\mathrm{Cu}(5.34 \mathrm{mg} / \mathrm{kg})$ and $\mathrm{K}(4,070 \mathrm{mg} / \mathrm{kg})$ grain concentrations were also found high in samples from Gotland. Low concentrations of Se $(0.04 \mathrm{mg} / \mathrm{kg}), \mathrm{Mg}(1,220 \mathrm{mg} / \mathrm{kg}), \mathrm{Zn}$ $(36.2 \mathrm{mg} / \mathrm{kg}$ ) and $\mathrm{Mn}(17.0 \mathrm{mg} / \mathrm{kg})$ were noticed in grain samples from Gotland (Table 2). The lowest concentration of $\mathrm{Fe}(33.1 \mathrm{mg} / \mathrm{kg})$ was found in grain samples from Gotland as compared to the other locations. 
Among locations, Uppsala showed the samples with the highest Fe (49.6 mg/kg), Zn (43.4 mg/kg), $\mathrm{Ca}(411 \mathrm{mg} / \mathrm{kg})$ and $\mathrm{S}(1,420 \mathrm{mg} / \mathrm{kg})$ concentrations in comparison with samples from all other locations. Low grain concentrations of $\mathrm{Mg}(1,210 \mathrm{mg} / \mathrm{kg})$ and $\mathrm{Mn}(17.0 \mathrm{mg} / \mathrm{kg})$ were noticed in samples from Uppsala (Table 2). Mo $(0.71 \mathrm{mg} / \mathrm{kg})$ grain concentration was significantly the lowest in samples from Uppsala compared to Alnarp, Bohuslän and Gotland.

\subsection{Difference between Spring and Winter Wheat}

The data of the present study showed significant differences in mineral concentration between spring and winter wheat (Table 2). Spring wheat samples were observed to have significantly higher values for the concentrations of B $(2.11 \mathrm{mg} / \mathrm{kg}), \mathrm{Cu}(5.62 \mathrm{mg} / \mathrm{kg}), \mathrm{Fe}(47.5 \mathrm{mg} / \mathrm{kg}), \mathrm{Zn}(41.2 \mathrm{mg} / \mathrm{kg})$, $\mathrm{Ca}(420 \mathrm{mg} / \mathrm{kg}), \mathrm{S}(1,430 \mathrm{mg} / \mathrm{kg})$ and $\mathrm{K}(4,160 \mathrm{mg} / \mathrm{kg})$ as compared to winter wheat samples. Significantly higher grain concentrations of Mo $(1.92 \mathrm{mg} / \mathrm{kg})$ and $\mathrm{P}(4,260 \mathrm{mg} / \mathrm{kg})$ were found in samples of winter wheat than in samples of spring wheat. The grain concentration of the minerals, Se, $\mathrm{Mg}$ and Mn did not differ significantly between spring and winter wheat samples (Table 2).

\subsection{Correlation of Yield and Plant Height with Mineral Concentration}

A negative correlation between yield and some of the evaluated minerals was found (Table 3 ). Thus, the grain concentrations of $\mathrm{Cu}(\mathrm{r}=-0.58), \mathrm{Fe}(\mathrm{r}=-0.50), \mathrm{Mg}(\mathrm{r}=-0.40), \mathrm{Zn}(\mathrm{r}=-0.66), \mathrm{P}(\mathrm{r}=-0.53)$ and $\mathrm{S}(\mathrm{r}=-0.40)$ were negatively correlated $(\mathrm{P}<0.05)$ with yield (Table 3$)$. Plant height was significantly positively correlated $(\mathrm{P}<0.05)$ with grain concentrations of $\mathrm{Cu}(\mathrm{r}=0.28), \mathrm{Mg}(\mathrm{r}=0.14)$, and $\mathrm{P}(\mathrm{r}=0.19)$ (Table 3).

Table 3. Spearman rank correlation coefficients among various minerals related to yield and plant height.

\begin{tabular}{|l|l|l|}
\cline { 2 - 3 } \multicolumn{1}{c|}{} & Yield & Plant height \\
\hline Number of samples & $\mathrm{n}=28$ & $\mathrm{n}=128$ \\
\hline B & -0.05 & 0.04 \\
Se & $-0.58^{* *}$ & $0.28^{* * *}$ \\
Fe & -0.02 & 0.12 \\
Mg & $-0.50^{* *}$ & 0.08 \\
Zn & $-0.40^{*}$ & $0.14^{*}$ \\
Ca & $-0.66^{* * *}$ & 0.10 \\
Mn & -0.13 & -0.10 \\
Mo & -0.26 & 0.04 \\
$\mathbf{P}$ & 0.19 & -0.05 \\
S & $-0.53^{* *}$ & $0.19^{* *}$ \\
K & $-0.40^{*}$ & 0.12 \\
\hline
\end{tabular}

$*, * *, * * *$ indicate significant at $\mathrm{p}<0.05,0.01,0.005$. Note: The yield was taken from 28 winter wheat genotypes grown in Bohuslän in bigger plots for reliable yield data. Plant height was measured for 128 winter wheat genotypes grown in Alnarp. 


\subsection{Importance of Genotype Group and Location on Concentration of Different Minerals}

Importance of genotype and location (measured by use of $\sigma_{\mathrm{g}}{ }^{2} / \sigma_{1}{ }^{2}$ ) for grain concentration of various minerals was found to vary in relation to genotype group and mineral. For selections, location was found more important than genotype for concentration of all minerals except for the concentrations of Se and Mo (Table 4). For old cultivars, influence of the genotype was higher as compared to location for grain concentration of $\mathrm{Fe}, \mathrm{Mg}, \mathrm{Mn}$ and $\mathrm{S}$. For the rest of the minerals (B, Cu, Se, Ca, Mo, P and K), location was found more important than genotype in old cultivars (Table 4).

Table 4. Ratio of genetic to locations variance $\left(\sigma_{\mathrm{g}}{ }^{2} / \sigma_{1}{ }^{2}\right)$ for various mineral concentrations in different genotype groups.

\begin{tabular}{|l|l|l|l|l|l|l|}
\hline Groups & Selections & Old cultivars & Primitive & Spelt & Landraces & Cultivars \\
\hline $\mathbf{B}$ & 0.20 & 0.69 & 2.35 & 1.41 & 0.96 & 0.62 \\
$\mathbf{C u}$ & 0.38 & 0.91 & 2.45 & 0.81 & 0.87 & 0.95 \\
$\mathbf{S e}$ & 1.19 & 0.71 & 1.92 & 1.09 & 0.85 & 0.95 \\
$\mathbf{F e}$ & 0.16 & 1.70 & 0.51 & 0.40 & 0.80 & 0.33 \\
$\mathbf{M g}$ & 0.55 & 1.04 & 1.69 & 0.82 & 0.88 & 0.69 \\
$\mathbf{Z n}$ & 0.71 & 1.00 & 1.49 & 0.94 & 0.79 & 1.20 \\
$\mathbf{C a}$ & 0.64 & 0.89 & 1.48 & 0.50 & 1.00 & 0.98 \\
$\mathbf{M n}$ & 0.30 & 1.21 & 0.69 & 0.69 & 1.08 & 0.73 \\
$\mathbf{M o}$ & 1.02 & 0.69 & 0.50 & 1.11 & 1.06 & 1.84 \\
$\mathbf{P}$ & 0.24 & 0.81 & 1.28 & 0.91 & 0.90 & 1.10 \\
$\mathbf{S}$ & 0.47 & 1.07 & 1.63 & 0.84 & 0.80 & 1.06 \\
$\mathbf{K}$ & 0.53 & 0.81 & 1.63 & 0.75 & 1.00 & 1.27 \\
\hline
\end{tabular}

Value: $<1$ indicates more influence of location than genotype on mineral concentration; >1indicates more influence of genotype than location on mineral concentration.

For primitive wheat, genotype variation had higher influence for concentration of several of the minerals i.e., $\mathrm{B}, \mathrm{Cu}, \mathrm{Se}, \mathrm{Mg}, \mathrm{Zn}, \mathrm{Ca}, \mathrm{P}, \mathrm{S}$ and $\mathrm{K}$ as compared to location. Also, primitive wheat generally showed higher influences from genotype on concentration of minerals as compared to most of the other genotype groups (values above 1 indicated a higher number of minerals than the other genotype groups, and also generally higher values). With exception of concentrations of B, Se, and Mo in spelt wheat, all other evaluated minerals were more influenced by location than genotypes (Table 4). For landraces, influence of genotype was more pronounced than location for concentrations of $\mathrm{Ca}, \mathrm{Mn}$, $\mathrm{Mo}$ and $\mathrm{K}$. For concentrations of $\mathrm{B}, \mathrm{Cu}, \mathrm{Se}, \mathrm{Fe}, \mathrm{Mg}, \mathrm{Zn}, \mathrm{P}$ and $\mathrm{S}$ location was more important than genotype among landraces. In cultivars, concentrations of Zn, Mo, P, S and K showed higher genotype influence than location (Table 4).

\section{Discussion}

The present study clearly showed the potential of producing wheat with exceptional high concentration of minerals by the use of specific genotypes in combination with organic cultivation (Table 5). Mean concentration of minerals from the organically produced whole grain flour in the present investigation was found to provide more than $70 \%$ of the daily intake of $\mathrm{Cu}, \mathrm{Se}, \mathrm{Fe}, \mathrm{Mg}, \mathrm{Zn}$, 
Mn, Mo and P. This calculation was based on statistics from FAO [24] that the mean consumption of wheat flour is about $200 \mathrm{~g}$ per person per day. Furthermore, the calculations were based on the values for recommended intake for adults according to DGE [25] as shown in Table 5. However, the percentage of minerals in wheat grain was found to vary with different factors like genotype, environment, farming conditions etc.

More than three billion population of the world is facing deficiency of minerals. Minerals deficiency results in low working efficiency, high healthcare costs and increased rates of premature death [26]. Population of developing countries is especially at risk, because the people do not have enough money to buy mineral rich food such as meat, poultry, fish, fruits and vegetables. Fe and $\mathrm{Zn}$ are major deficient nutrients in the world [11]. The key factor for deficiency of Fe and $\mathrm{Zn}$ is the low concentrations in cereals [27]. Emphasis has been given on screening wheat genetic material for high concentrations of $\mathrm{Fe}$ and $\mathrm{Zn}$ within a large project led by the International Maize and Wheat Improvement Centre (CIMMYT) [28]. Thus, using specific genotypes in organic system might be the best tool to meet the minerals deficiency in humans.

In the present study high mean levels of most of the minerals were found as compared to previous studies (Table 5). The high mean levels were found despite the fact that a range of different types of wheat and wheat cultivars was included in this investigation. To our knowledge, all previous investigations in which genotypic variation in mineral concentration has been evaluated, except Ryan [14] have been carried out under inorganic conditions. Thus, the high concentration of minerals in the present study might be attributed to the organic farming system used and reflects the influence of soil supply of nutrients, efficiency of genotype uptake and yield. However, from previous studies $[14,15]$ it might be concluded that an organic system by itself is not the clue of producing highly nutritious wheat in terms of mineral composition and concentration. Comparative studies have shown non significant differences in grain concentration of most minerals for wheat produced in organic and inorganic farming systems. In these studies, similar genotypes, mostly modern cultivars bred for inorganic systems, were grown under both systems [14,15]. However, the specific genotype can be a central factor to consider in organic farming systems. It is well known that the genotypes and production system interaction have a significant effect upon the performance of a genotype in a cropping system [29]. Genotypes that are bred for organic farming systems normally differ from those bred for inorganic systems in specific characters such as competitive ability with weeds, plant height, disease resistance, root system and nutrient use efficiency [30].

Considerable differences between grain concentrations of various minerals were not only found among genotypes, but also among genotype groups and type of wheat. The large variation among genotype, genotype groups and wheat type indicate the genetic potential that can be used to modify the minerals concentration in health promoting direction in wheat.

Generally, higher mineral concentration was observed for several of the investigated minerals in selections, primitive wheat, and old cultivars as compared to more modern wheat material, like e.g., cultivars and spelt wheat. However, for other minerals the relationship that more recent material showed lower concentrations of minerals could not be proven in the present investigation. Earlier investigations have indicated a negative correlation between more recent cultivars and amount of minerals [31]. This relationship has been attributed to a dilution effect of the minerals due to the increased yield of most recent cultivars [31]. Thus, in conclusion, the present study only partially agrees with previous results indicating decreasing mineral density in wheat over the last 160 years [31]. 
Table 5. Comparison of mineral concentration $(\mathrm{mg} / \mathrm{kg})$ in the present study with previous studies, recommended intake of minerals and percentage of recommended intake of minerals from flour consumption $200 \mathrm{~g} /$ person/day. This study was performed in organic system while rest of the studies, except Ryan et al. [14] were carried out under inorganic condition.

\begin{tabular}{|c|c|c|c|c|c|c|c|c|c|}
\hline & $\begin{array}{l}\text { Present } \\
\text { study }\end{array}$ & $\begin{array}{l}\text { Spiegel et al., } \\
2009 \text { [40] }\end{array}$ & $\begin{array}{c}\text { Zhao et al., } \\
2009[12]\end{array}$ & $\begin{array}{l}\text { Kirchmann et al., } \\
2009 \text { [42] }\end{array}$ & $\begin{array}{l}\text { Fan et al., } \\
2008[31]\end{array}$ & $\begin{array}{c}\text { Ryan et al., } \\
2004[14]\end{array}$ & $\begin{array}{c}\text { Graham et al., } \\
1999[11]\end{array}$ & $\begin{array}{c}\text { Recommended } \\
\text { intake (mg/day) } \\
\text { according to DGE } \\
2001[25] \\
\end{array}$ & $\begin{array}{c}\text { Percentage of } \\
\text { recommended intake } \\
\text { from flour consumption } \\
200 \mathrm{~g} / \mathrm{person} / \mathrm{day}\end{array}$ \\
\hline B & 1.96 & 0.69 & n.a & n.a & n.a & & 2.3 & 1 & 39 \\
\hline $\mathrm{Cu}$ & 5.26 & 3.9 & n.a & 3.51 & 4 & 3.3 & n.a & 1.5 & 70 \\
\hline Se & 0.11 & n.a & 0.09 & 0.03 & n.a & n.a & n.a & $0.03-0.07$ & $31-73$ \\
\hline $\mathbf{F e}$ & 37.9 & 31 & 38.2 & 30.3 & 30.4 & 18 & 37.2 & 10 & 76 \\
\hline Mg & 1,261 & 1,208 & n.a & n.a & 1,015 & 630 & 1,130 & $300-350$ & $72-84$ \\
\hline $\mathbf{Z n}$ & 38.9 & 23.9 & 21.4 & 27.3 & 27.4 & 25 & 35.0 & 10 & 78 \\
\hline $\mathrm{Ca}$ & 378 & 284 & n.a & n.a & n.a & 420 & 416 & 1,000 & 8 \\
\hline Mn & 22.5 & 36.9 & n.a & 33.3 & n.a & 41 & 44.7 & 5 & 90 \\
\hline Mo & 1.71 & 0.81 & n.a & 1.19 & n.a & n.a & n.a & $0.05-0.1$ & $>100$ \\
\hline $\mathbf{P}$ & 4,124 & 3,293 & n.a & n.a & n.a & 2,800 & 3,380 & 700 & $>100$ \\
\hline $\mathbf{S}$ & 1,298 & n.a & n.a & n.a & n.a & 1,400 & 1,670 & $850-1,500$ & $17-30$ \\
\hline $\mathbf{K}$ & 4,075 & 3,289 & n.a & n.a & n.a & 4,000 & 3,600 & 2,000 & 41 \\
\hline
\end{tabular}

n.a indicates not analyzed. 
Our results showed that spring wheat generally contained higher concentrations of most minerals as compared to winter wheat. The decreased grain mineral concentration in winter wheat may be linked to a dilution effect because of their higher yield as compared to spring wheat. Also, a negative relationship was observed between the yield and mineral concentration in the present study. Findings of a negative relationship between yield and mineral concentration have been reported from other studies $[12,32,33]$ although contrasting findings are present with a positive relationship between yield and mineral density [11]. Contrastingly, addition of fertilizer to get high yield in similar genotypes did not influence the concentration of minerals in grain [34]. Further, plant height of winter wheat $(n=128)$ were found to have a significant and positive correlation $(\mathrm{P}<0.05)$ with $\mathrm{Cu}, \mathrm{Mg}$ and $\mathrm{P}$. Positive relationship of some minerals with plant height was also reported in earlier studies $[12,31]$.

The amount of different minerals in the grain depends on the levels transported by roots during grain development and amount redistributed to the grain by vegetative tissue through the phloem [35]. Photosynthetic activity of vegetative tissue is an important factor in determining grain mineral concentration as well as the yield. Different wheat genotypes vary in photosynthesis and chlorophyll concentration [36]. Correlation between the chlorophyll and Fe concentration was reported by Dias et al. [37]. They found that higher chlorophyll content at final grain filling increased the amount of Fe in the grain [37]. Carbon dioxide enrichment was found to inhibit the assimilation of nitrate to organic nitrogen compounds. Low availability of nitrogen lead to reduced photosynthesis in wheat plant, also negatively affecting the grain quality e.g., mineral concentration [38].

From the present study, it appears that genetic differences are important in determination of mineral concentration of the wheat grain. Genetic difference for grain mineral concentration has also been reported from various varietal trials $[9,11,12]$.

Ratio between genetic group and location variances $\left(\sigma_{\mathrm{g}}{ }^{2} / \sigma_{1}{ }^{2}\right)$ is helpful to measure the influences of genotype and location on the mineral composition of wheat. In this study, the genotype was found to have more impact on the mineral composition than location for primitive wheat. Thus, this strengthens the idea that primitive wheat genotypes can be used in organic farming system to enhance the mineral levels in wheat grain. In contrast, a previous study showed that relative influence of environment is higher than genotype for most of the wheat minerals [9].

Growing environment of different locations has an influence on mineral levels in grain [11]. In the present study, mineral concentration in the wheat grown in different locations was significantly different $(\mathrm{P}<0.05)$. Variation in mineral elements of grain might be dependent on the soil characteristics of a particular location (Table 1). Cultivation in Alnarp and Gotland led to highest grain concentration of some of the minerals as compared to cultivation in Bohuslän and Uppsala. Increased organic matter percentage and $\mathrm{pH}$ of these locations might be the reason for higher mineral concentration. These findings are in accordance with previous studies which showed that high organic matter and $\mathrm{pH}$ favour the mineral concentration in the wheat grain $[39,40]$. Our material grown over six years did not show significant variation due to years. However, larger material grown over a number of years might show yearly variation as has been shown by [40].

In the present investigation, the mean mineral concentration in some genotypes were exceptionally high and were found to contribute near to $100 \%$ of recommended daily intake of most of the minerals. The wheat genotypes with the exceptionally high concentration of minerals under the used organic system came from all of the wheat genotype groups that were evaluated in the present investigation. 
Thus, these findings did not contribute to the idea that the old and more primitive wheat had higher potential to produce exceptionally high concentration of minerals in the grain under organic conditions. More important seemed the selection of the most optimal genotype for the production of high grain mineral concentration. For consumption of organic wheat, it is important to have in mind that concentration of minerals in the grain is dependent on which part of the grain that is used [41]. However, one idea of organic wheat grain consumption is to use whole grain flour products in order to receive high nutrition value in the food.

\section{Conclusions}

Wheat grain with high mineral nutritional value can be produced by using specific genotypes under organic cultivation. Mineral concentrations of organically grown wheat are higher than those seen in previous studies in inorganic systems. Thus, consumption of organically grown wheat flour could be a new strategy to alleviate human micronutrient undernutrition. Variation in mineral composition of different genotypes was found in this study, which can be used in further breeding to improve the nutritional quality of wheat grain.

By the choice of "the right" wheat genotypes together with suitable growing conditions i.e., organic, it is possible to ensure almost daily requirements of minerals in the produced wheat. Examples of genotypes resulting in high mineral concentrations were Lant vete Gotland, Triticum monococcum, $T$. dicoccum, Lv. Dal, Olands Urval, T. Polonicum, APU and Schweiz.

\section{Acknowledgements}

Authors would like to acknowledge "The Swedish Farmers Foundation for Agricultural Research (SLF)" for project grants and Higher Education Commission, Pakistan for financial support to Abrar Hussain. We are also thankful to Tommy Olsson from Lund University for his technical assistance during the chemical analysis.

\section{References}

1. Martinez-Ballesta, M.C.; Dominguez-Perles, R.; Moreno, D.A.; Muries, B.; Alcaraz-Lopez, C.; Bastias, E.; Garcia-Viguera, C.; Carvajal, M. Minerals in plant food: effect of agricultural practices and role in human health. A review. Agron. Sustain. Dev. 2009, 30, 295-309.

2. Golden, M.H.N. The nature of nutritional deficiency in relation to growth failure and poverty. Acta Paediat. Scand. 1991, 374, 95-110.

3. Branca, F.; Ferrari, M. Impact of micronutrient deficiencies on growth: The stunting syndrome. Ann. Nutr. Metab. 2002, 46, 8-17.

4. Galan, P.; Preziosi, P.; Durlach, V.; Valeix, P.; Ribas, L.; Bouzid, D.; Favier, A.; Hercberg, S. Dietary magnesium intake in a French adult population. Magnes. Res. 1997, 10, 321-328.

5. Dikeman, E.; Pomeranz, Y.; Lai, F.S. Minerals and protein contents in hard red winter-wheat. Cereal Chem. 1982, 59, 139-142.

6. Lopez, H.W.; Krespine, V.; Lemaire, A.; Coudray, C.; Feillet-Coudray, C.; Messager, A.; Demigne, C.; Remesy, C. Wheat variety has a major influence on mineral bioavailability; Studies in rats. J. Cereal Sci. 2003, 37, 257-266. 
7. Toepfer, E.W.; Slover, H.T.; Hepburn, F.N.; Polansky, M.M.; Morris, E.R.; Eheart, J.F.; Quackenb. F.W. Nutrient composition of selected wheats and wheat products. XI. summary. Cereal Chem. 1972, 49, 173-186.

8. Peterson, C.J.; Johnson, V.A.; Mattern, P.J. Evaluation of variation in mineral element concentrations in wheat-flour and bran of different cultivars. Cereal Chem. 1983, 60, 450-455.

9. Peterson, C.J.; Johnson, V.A.; Mattern, P.J. Influence of cultivar and environment on mineral and protein concentrations of wheat-flour, bran, and grain. Cereal Chem. 1986, 63, 183-186.

10. Davis, K.R.; Peters, L.J.; Cain, R.F.; LeTourneau, D.; McGinnis, J. Evaluation of the nutrient composition of wheat. III. Minerals. Cereal Food World 1984, 29, 246-248.

11. Graham, R.; Senadhira, D.; Beebe, S.; Iglesias, C.; Monasterio, I. Breeding for micronutrient density in edible portions of staple food crops: Conventional approaches. Field Crop. Res. 1999, $60,57-80$.

12. Zhao, F.J.; Su, Y.H.; Dunham, S.J.; Rakszegi, M.; Bedo, Z.; McGrath, S.P.; Shewry, P.R. Variation in mineral micronutrient concentrations in grain of wheat lines of diverse origin. $J$. Cereal Sci. 2009, 49, 290-295.

13. Bourn, D.; Prescott, J. A comparison of the nutritional value, sensory qualities, and food safety of organically and conventionally produced foods. Crit. Rev. Food Sci. Nutr. 2002, 42, 1-34.

14. Ryan, M.; Derrick, J.; Dann, P. Grain mineral concentrations and yield of wheat grown under organic and conventional management. J. Sci. Food Agri. 2004, 84, 207-216.

15. Nitika; Darshan, P.; Khetarpaul, N. Physico-chemical characteristics, nutrient composition and consumer acceptability of wheat varieties grown under organic and inorganic farming conditions. Int. J. Food Sci. Nutr. 2008, 59, 224-245.

16. Koivistoinen, P.; Nissinen, H.; Varo, P.; Ahlstrom, A. Mineral element composition of cereal grains from different growing areas in Finland. Acta Agr. Scand. 1974, 24, 327-334.

17. Maeder, P.; Hahn, D.; Dubois, D.; Gunst, L.; Alfoeldi, T.; Bergmann, H.; Oehme, M.; Amado, R.; Schneider, H.; Graf, U.; Velimirov, A.; Fliebbach, A.; Niggli, U. Wheat quality in organic and conventional farming: Results of a 21 year field experiment. J. Sci. Food Agr. 2007, 87, 1826-1835.

18. Padel, S.; Lampkin, N.; Foster, C. Influence of policy support on the development of organic farming in the European Union. Int. Plan. Stud. 1999, 4, 303-315.

19. Lairon, D. Nutritional quality and safety of organic food. A review. Agron. Sustain. Dev. 2009, 30, $33-41$.

20. Grausgruber, H.; Scheiblauer, J.; Schonlechner, R.; Ruckenbauer, P.; Berghofer, E. Variability in Chemical Composition and Biologically Active Constituents of Cereals. In Genetic Variation for Plant Breeding; Proceedings of the 17th EUCARPIA General Congress, Tulln, Austria, 8-11 September 2004; pp. 23-26.

21. Hammer, K. Biodiversity of the genus Triticum. In Organic Plant Breeding and Biodiversity of Cultural Plants; Wiethaler, C., Oppermann, R., Wyss, E., Eds.; Reports on the International Conferences. Naturschutzbund Deutschland and Research Institute of Organic Agriculture. 2000; pp. 72-81.

22. Tyler, G.; Olsson, T. Conditions related to solubility of rare and minor elements in forest soils. $J$. Plant Nutr. Soil Sci. 2002, 165, 594-601. 
23. Delin, S.; Soderstrom, M. Performance of soil electrical conductivity and different methods for mapping soil data from a small dataset. Acta Agr. Scand. Sect. B-Soil Pl. 2003, 52, 127-135.

24. FAO (Food and Agriculture Organization). Food supply; Available online: http://faostat.fao.org/ site/609/DesktopDefault.aspx?PageID=609.(accessed on 09 December 2005).

25. DGE (German Nutrition Society). Referenzwerte fur die Nährstoffzufuhr, 1. Auflage; Hrs. DGE, ÖGE, SGE und SVE, 1st ed.; Umschau/Braus: Frankfurt, Germany, 2001.

26. Welch, R.M.; Graham, R.D. Breeding for micronutrients in staple food crops from a human nutrition perspective. J. Exp. Bot. 2004, 55, 353-364.

27. Hurrell, R.F. Modifying the composition of plant foods for better human health. In Crop Science: Progress and Prospects; Proceedings of the Third International Crop Science Congress, Hamburg, Germany, 17-22 August 2000; pp. 53-64.

28. Monasterio, I.; Graham, R.D. Breeding for trace minerals in wheat. Food Nutr. Bull. 2000, 21, 392-396.

29. Murphy, K.M.; Campbell, K.G.; Lyon, S.R.; Jones, S.S. Evidence of varietal adaptation to organic farming systems. Field Crop. Res. 2007, 102, 172-177.

30. van Bueren, E.T.L.; Struik, P.C.; Tiemens-Hulscher, M.; Jacobsen, E. Concepts of intrinsic value and integrity of plants in organic plant breeding and propagation. Crop Sci. 2003, 43, 1922-1929.

31. Fan, M.; Zhao, F.; Fairweather-Tait, S.J.; Poulton, P.R.; Dunham, S.J.; McGrath, S.P. Evidence of decreasing mineral density in wheat grain over the last 160 years. J. Trace Elem. Med. Biol. 2008, 22, 315-324.

32. Garvin, D.F.; Welch, R.M.; Finley, J.W. Historical shifts in the seed mineral micronutrient concentration of US hard red winter wheat germplasm. J. Sci. Food Agr. 2006, 86, 2213-2220.

33. McDonald, G.K.; Genc, Y.; Graham, R.D. A simple method to evaluate genetic variation in grain zinc concentration by correcting for differences in grain yield. Plant Soil 2008, 306, 49-55.

34. McGrath, S.P. The effects of increasing yields on the macroelement and microelement concentrations and off takes in the grain of winter-wheat. J. Sci. Food Agr. 1985, 36, 1073-1083.

35. Garnett, T.P.; Graham, R.D. Distribution and remobilization of iron and copper in wheat. Ann. Bot. 2005, 95, 817-826.

36. Alkhatib, K.; Paulsen, G.M. Photosynthesis and productivity during high-temperature stress of wheat genotypes from major world regions. Crop Sci. 1990, 30, 1127-1132.

37. Dias, A.S.; Lidon, F.C.; Ramalho, J.C. IV. Heat stress in Triticum: kinetics of $\mathrm{Fe}$ and $\mathrm{Mn}$ accumulation. Braz. J. Plant Physiol. 2009, 21, 153-164.

38. Bloom, A.J.; Burger, M.; Asensio, J.S.R.; Cousins, A.B. Carbon dioxide enrichment inhibits nitrate assimilation in wheat and arabidopsis. Science 2010, 328, 899-903.

39. Murphy, K.; Hoagland, L.; Reeves, P.; Jones, S. Effect of cultivar and soil characteristics on nutritional value in organic and conventional wheat. In Proceedings of the 16th IFOAM Organic World Conference in Cooperation with the International Federation of Organic Agriculture Movements (IFOAM) and the Consorzio ModenaBio., Modena, Italy, 18-20 June 2008; pp. 614-617.

40. Spiegel, H.; Sager, M.; Oberforster, M.; Mechtler, K.; Stueger, H.P.; Baumgarten, A. Nutritionally relevant elements in staple foods: Influence of arable site versus choice of variety. Environ. Geochem. Health 2009, 31, 549-560. 
41. Liu, Z.H.; Wang, H.Y.; Wang, X.E.; Zhang, G.P.; Chen, P.D.; Liu, D.J. Phytase activity, phytate, iron, and zinc contents in wheat pearling fractions and their variation across production locations. J. Cereal Sci. 2007, 45, 319-326.

42. Kirchmann, H.; Mattsson, L.; Eriksson, J. Trace element concentration in wheat grain: Results from the Swedish long-term soil fertility experiments and national monitoring program. Environ. Geochem. Health 2009, 31, 561-571.

(C) 2010 by the authors; licensee MDPI, Basel, Switzerland. This article is an open access article distributed under the terms and conditions of the Creative Commons Attribution license (http://creativecommons.org/licenses/by/3.0/). 